\title{
Recurrent multiple amoebic liver abscesses
}

\author{
Adina llie*, Ramona Popescu, Gabriel Colțan \\ From The 9th Edition of the Scientific Days of the National Institute for Infectious Diseases Prof Dr Matei \\ Bals \\ Bucharest, Romania. 23-25 October 2013
}

\section{Background}

We present the management of recurrent liver microabscesses after stopping antibiotic therapy in a patient with no significant pathology associated.

\section{Case report}

A female patient was admitted to our ward for fever 3 days after stopping therapy with ertapenem and metronidazole from a previous hospitalization.

From the medical history we mention that the patient had had two other episodes of liver microabscesses which responded well and promptly to antibiotic regimens that had in common metronidazole. The patient was screened for HIV, HTLV, tuberculosis, endocarditis, hydatid cyst, cancer - results came back negative.

The patient had no context of amoebic liver abscess: Romania is not an endemic area, the patient had not travelled across the border, screening for amoebic coproantigen was negative; all we had to go on was the fact that fever and liver abscesses disappeared under metronidazole treatment alone.

After diagnosis was confirmed, for complete treatment we had to use drugs active also against the intestinal cyst form of Entamoeba histolytica, difficult given their limited availability in Romania. After the full course of treatment, the patient has fully recovered.

\section{Conclusion}

When you are confronted with invasive disease caused by $E$ histolytica it is mandatory to treat the cystic form.
Published: 16 December 2013

doi:10.1186/1471-2334-13-S1-P96

Cite this article as: Ilie et al:: Recurrent multiple amoebic liver abscesses. BMC Infectious Diseases 2013 13(Suppl 1):P96.
* Correspondence: adinailie00@yahoo.com

National Institute for Infectious Diseases "Prof. Dr. Matei Balş", Bucharest, Romania
Submit your next manuscript to BioMed Central and take full advantage of:

- Convenient online submission

- Thorough peer review

- No space constraints or color figure charges

- Immediate publication on acceptance

- Inclusion in PubMed, CAS, Scopus and Google Scholar

- Research which is freely available for redistribution

Submit your manuscript at www.biomedcentral.com/submit
C Bïomed Central 